\title{
The tardigrade and associated micrometazoa of the textured lungwort lichen, Lobaria scrobiculata, in eastern Newfoundland, Canada
}

\author{
Michael Collins \\ Dept. of Biology \\ Memorial University of Newfoundland \\ St. John's, NL A1B 3X9 \\ Canada \\ Ian Goudie \\ Harlequin enterprises \\ Box 132 Site 3, St. Catherines, NL A0B 2M0 \\ Canada
}

\begin{abstract}
Thirty-eight samples of the textured lungwort lichen, Lobaria scrobiculata, were collected from tree trunks in two sites on the Avalon Peninsula of the Island of Newfoundland, Canada. These samples yielded 340 tardigrade specimens the most numerous species being Hysibius convergens, Claxtonia merokensis, Echiniscus wendti, Macrobiotus cf.hufelandi and Milnesium sp. Several species reckoned to be rare on the island as a result of previous studies of ground growing lichens and mosses were exceptionally common in Lobari ascrobiculata demonstrating the importance of tree trunks as an environment supporting tardigrades. Rotifers and nematodes were also recovered but were not as numerous as tardigrades. L. scrobiculata is often co-located with the rare boreal felt lichen Erioderma pedicellatum, also a foliose lichen, and it is hoped that the information from this present study can also be applied in the conservation of this rare lichen.
\end{abstract}

Keywords: Tardigrade, lichen, micrometazoa, rotifer, nematode

\section{Introduction}

The tardigrade fauna of the textured lungwort lichen, Lobaria scrobiculata, a foliose lichen, were extracted from 38 samples of the lichen collected in conifer forests at two sites, Long Harbour (47.4 N; 53.8 E) and Lockyer's Waters (47.3 $\mathrm{N} ; 53.3 \mathrm{E}$ ), on the Avalon Peninsula of eastern Newfoundland, Canada, the most easterly part of North America. In these two areas this lichen grows extensively on balsam fir, Abies balsamea, in the highly oceanic forests where it is part of a community of cyanolichens typical for old growth forest in Newfoundland (Goudie 2011). The globally endangered boreal felt lichen, Erioderma pedicellatum, is also a member of the cyanolichen community in these areas and grows in close association with $L$. scrobiculata. As $L$. scrobiculata and E. pedicellatum are both foliose lichens growing on balsam fir, often together, it was hoped that the information on the micrometazoa of L.scrobiculata might also provide information on the micrometazoa living in the E. pedicellatum which could prove useful in future studies of the conservation of this rare lichen which could not be sampled directly due to its rare status.

\section{Method}

Lichen samples were provided from two sites in eastern Newfoundland, Canada, namely Lockyer's Waters and Long Harbour, both on the Avalon Peninsula, in the fall of 2014. Intact thalli were removed from host trees,including six samples taken from Lockyer's Waters between 21 October 2014 (LWSC 01 to LWSC 06), and thirty-two from Long Harbour between 29 October 2014 and 12 November 2014 (LHSC 01 to LHSC 32).

Samples were stored in brown paper bags and were allowed to dry out naturally so that any tardigrades on the lichens would enter the cryptobiotic state and remain in that state until they were examined later in the laboratory. Extraction was undertaken by placing each specimen, or part of the lichen if the whole lichen was too large to fit in a small petri dish, upside down in a $5 \mathrm{~cm}$ diameter petri dish and covered with tap water so that any tardigrades would come out of their cryptobiotic state and resume normal activity. The samples were left for at least 24 hours (Kinchin 1994) so that all specimens had enough time to exit cryptobiosis, as different species take different times to resume normal activities. Each thallus was then washed off with water from a squeegee to ensure removal of all the tardigrades, and other micrometazoa, from the sample. 
The petri dish was then examined under a Bausch and Lomb stereo dissecting microscope (20-40 magnification) and each specimen removed with a fine pipette and transferred to a microscope slide for more detailed examination under a Carton Optical Binocular Stereoscope. If the specimen could not be identified at this magnification it was then mounted in Hoyer's solution (Kinchin 1994), covered with a cover slip, and allowed to dry over a three-week period. After this time period, the specimen was examined under high power and viewed on a Toshiba laptop computer screen connected to an Infinity 1 electronic camera on the microscope and images were saved for further examination.

\section{Results}

\subsection{Tardigrades}

In all, some 340tardigrades were extracted and identified from these lichen samples (the two Echiniscid specimens not identified to species were simplex forms and probably either E. merokensis or C.wendti). Two specimens were lost in the transfer from the petri dish to a microscope slide and so were not identified, leaving 338 identified specimens. The most commonly found species was Hypsibius convergens(Urbanowicz, 1925), accounting for $28.5 \%$ of all the identified specimens recovered. The second most commonly extracted species was Echiniscus merokensisRichters, 1904, (18.8\%) followed by Macrobiotus cf. hufelandi C.A.S.Schultze, 1834 (16.2\%), and Milnesium sp.(14.4\%). C.wendti Richters, 1903 was also quite common $(13.8 \%)$ in these samples.

Table 1. The species and numbers of tardigrade specimens recovered from the samples of lichens in eastern Newfoundland, Canada

$\begin{array}{llc}\text { Species } & \text { Number } & \text { \% of total } \\ \text { Diphascon (Diphascon) nodulosum } & 3 & 0.9 \\ \text { Echiniscus merokensis } & 64 & 18.8 \\ \text { Claxtonia wendti.. } & 47 & 13.8 \\ \text { Echiniscus sp. } & 2 & 0.6 \\ \text { Hypsibius convergens } & 97 & 28.5 \\ \text { Hypsibius dujardini } & 1 & 0.3 \\ \text { Isohypsibius prosostomus } & 1 & 0.3 \\ \text { Macrobiotus crenulatus } & 9 & 2.7 \\ \text { Macrobiotus cf.hufelandi } & 49 & 16.2 \\ \text { Mesobiotus harmsworthi } & 1 & 0.3 \\ \text { Milnesium sp. } & 49 & 14.4 \\ \text { Minibiotus intermedius } & 9 & 2.7\end{array}$

(Not including the two lost specimens)

All of these eleven species had been recorded previously for the island (Bateman \& Collins 2001) in ground lichens and mosses. M. cf. hufelandi, $(n=49)$, commonly found in these lichen samples, was also the most commonly found tardigrade in the previous studies of ground mosses and lichens in Newfoundland (Bateman \& Collins 2001, Collins \& Bateman 2012).

$H$. convergens was the most commonly found tardigrade in the samples, being found in $60 \%$ of all samples. $M$. cf. hufelandi was almost as frequently (57.9\%) found in samples as H. convergens. While E. merokensis was found in larger numbers than $C$. wendti, each was likely to be found in the same percentage of samples (39.4\%). Milnesium was located in just over one third of all the samples.

\section{Table 2. Frequency of occurrence of commonly extracted species in the 38 lichen samples}

$\begin{array}{lcc}\text { Species } & \text { Number of samples } & \text { \% of samples } \\ & \text { in which species found } & \text { in which species found } \\ \text { Echiniscus merokensis } & 15 & 39.4 \\ \text { Claxtonia wendti } & 15 & 39.4 \\ \text { Hypsibius convergens } & 23 & 60.5 \\ \text { Macrobiotus } \text { cf. hufelandi } & 22 & 57.9 \\ \text { Milnesium } \text { sp. } & 13 & 34.2\end{array}$

While tardigrades were extracted from all 38 samples, both the number of species and the total number of specimens in each sample varied widely. Eleven species were identified in this study but no individual sample had more than five 
different tardigrade species (Table 3). Ten of the thirty eight samples contained just one species while just two samples showed five species, the most observed in any sample.

Table 3. Numbers of Tardigrade species in the lichen samples

Number of species

1

2

3

4

5

Total
Number of samples

10
8
9
7
2
$36 *$

10

$36^{*}$

The actual number of tardigrades in each sample also varied tremendously from just one (seven samples) to as many as 44 (one sample). Half of the samples had between one and five specimens. The mean number of tardigrades in the samples was 9.0.

Table 4. Numbers of Tardigrade specimens in the lichen samples

Number of specimens in sample

$$
1-5
$$

$6-10$

$11-15$

$16-20$

$20+$

Total
Number of samples

19

7

6

1

5

$\overline{38}$

\subsection{Other micrometazoa and protozoa}

While the primary aim of this investigation was to extract and identify any tardigrades found in the lichen samples, note was taken of other micrometazoa also extracted from the lichen samples. Rotifers and nematodes, which are also often found in lichens and mosses (Kinchin 1992), were found in most of the samples. While tardigrades were found in all thirty eight samples, rotifers were recovered in 32 samples and nematodes in twenty seven. Euplotes-like protozoans were encountered in all 38 samples usually in very large numbers.

While no attempt was made to identify all the various nematodes, a number of them were extracted and mounted on microscope slides. All but one were identified as belonging to the genus Eudorylaimus. This type of nematode is a predator known to feed on mite eggs, although it has been known to feed on blue-green and green algae, as well as protozoa and fungi. The remaining nematode was identified as a member of the Bunorematiae, a group about which little is known (Finney-Crawley, pers com). All the rotifers examined were Bdelloids which are filter feeders on algae and protozoa.

\section{Discussion}

\subsection{Tardigrades of the tree trunk}

This is the first investigation of tardigrades on tree lichens on the Island of Newfoundland. Previous collections on the island of Newfoundland have been of tardigrades in lichens and mosses on the ground (Collins \& Bateman 2012).Our study demonstrated the importance of including samples of tree lichens (and presumably) mosses in determining the populations of terrestrial tardigrades in an area.

While no new species were recovered in this study it has shown that a number of species previously thought to be rare on the island are actually commonly found in arboreal situations. While all the species of tardigrades identified in this study had been found previously on the island, the most surprising aspect of this study was the number of H. convergens, E. merokensis, C.wendti and Milnesium sp. extracted from the lichen samples. Earlier studies of the (ground) mosses and lichens of the Island of Newfoundland considered the two heterotardigrade species to be extremely rare with just one specimen of C.wendti, and two specimens of E. merokensis (from the same site) having been located. In this present study of tree lichens both species were extremely common. Similarly the previous studies located only eight Milnesium sp. specimens from six sites on the island, and just sixteen specimens of $H$. convergens (Bateman \& Collins 2001, Collins \& Bateman 2012). M. cf. hufelandi commonly found in this present study was the most commonly found tardigrade in the previous studies of ground lichens and mosses. 
Tardigrades are commonly located on lichens (Argue 1971, Beasley 1978, Hidalgo \& Coombs 1985, and Horning et al 1978) while Stubbs (1989), Kinchin(1992), Bartels \& Nelson (2007), and Chang et al (2015) have all recorded tardigrades from tree lichens. Stubbs (1989) suggested that lichens are good substrates for tardigrades. Little is known about tardigrade life histories but some species are known to be predatory, and lichens support a wide variety of proteinaceous food items, including protozoa and rotifers (Uetz et al1980). Corticolous lichens (i.e., lichens that grow on bark and which would include L. scrobiculata) function as important resources for arthropoda, rotifera and tardigrada according to Stubbs (1989).

\subsection{Tardigrade feeding relationships}

Tardigrade buccal-pharyngeal structure is related to their feeding habits (Hallas \&Yeates 1972,Guidetti et al 2012,Guil\& Sanchez-Moreno 2013). Guil\& Sanchez-Moreno (2013) identified three basic groups of tardigrades namely, carnivores, herbivores and microbivores. Carnivores such as Milnesium and Macrobiotus have short wide buccal tubes and large pharynxes, while herbivores such as Echiniscus and Hypsibius have narrow, buccal tubes and weak stylets. Microbivores such as Diphascon (and Pilatobius, now separated off from the genus Diphascon) have long narrow, and partially flexible buccal tubes and feed on bacteria, fungi and/or detritus (Nelson et al 2018). More recently, however, Bryndováet al (2020) have classified tardigrades as carnivores, herbivores or omnivores, the latter differing from Guil\& SanchezMoreno's classification. Perhaps then we should classify four different feeding habits of tardigrades namely carnivore, herbivore, omnivore (both carnivorous and herbivorous as the situation requires) and microbivore, the latter having such narrow buccal tubes seemingly specialized for feeding on very small organisms (e.g. bacteria) and which cannot therefore be carnivorous.

In their study of the feeding habits of three different tardigrades, Bryndová et al(2020) confirmed that Milnesium inceptum was a carnivore, and Hypsibius exemplariswas an herbivore, feeding on cyanobacteria, algae, and fungi. Paramacrobiotus sp. was an omnivore feeding on cyanobacteria, algae, fungi and other animals. While these specific species were not encountered in the present study it would seemto confirm that Milnesium species are carnivores, Hypsibiidsare herbivores, while Macrobiotids (Macrobiotus, Mesobiotus) are perhaps omnivores rather than just carnivores, as also would be Isohypsibius. Diphascon and Pilatobius, which were not included in the studies of Bryndová et al would best be classified as microbivores based on the classification of Guil\& Sanchez-Moreno (2013) because of their long, narrow, flexible buccal tubes.Some species of tardigrades may browse cyanobacteria and other components of the cortex of lichens.

It is highly probable then that Milnesium sp. and perhaps also Macrobiotus cf.hufelandi, M. crenulatus, M. harmsworthi and Isohypsibius are feeding on the smaller tardigrades (e.g., Echiniscids and Hypsibiids) as well as nematodes and rotifers, which were also found in most of the lichen samples. It is probable that Pilatobius is feeding on protozoa which were visible in large numbers in most of the lichens, and also on bacteria.

The lichen ecosystem, however, is not a closed one, and other animal species may be found on occasion. Kinchin (1992) points out that in addition to the 'aquatic' fauna of a lichen (or moss) typically dominated by nematodes, rotifers and tardigrades, there are also the 'terrestrial' fauna dominated by arthropods (e.g., mites, collembolans, springtails etc.). However, few arthropods spend their whole life cycles within the lichen thallus. Other 'visitors' may include beetles, spiders and molluscs.

On the Island of Newfoundland, studies of the rare E. pedicellatum(often co-located with L. scrobiculata) reported frequent browsing of thalli, often visible as small $(\sim 1 \mathrm{~mm})$ circular depressions in the cortex (Goudie et al 2011) that were presumed to be attributable to mites (C. Sheidegger perscomm) rather than tardigrades.An array of species of oribatid mites was identified in old balsam fir forests on the Island of Newfoundland (Thompson et al 2013). E. pedicellatum is part of the Lobarion group of cyanolichens, and certain species of tardigrades (such as Hypsibiids and Echiniscids) likely forage on the blue-green bacteria of these cyanolichens.

\subsection{Densities and diversity of tree canopy micrometazoa}

Historically, terrestrial tardigrades have been collected within reach of the ground but Kimmel \&Meglitsch (1969) documented tardigrades in the forest canopy three meters above ground level in trees in Iowa and Voegtlin (1982) reported tardigrades in the washings of Douglas Fir needles in Oregon. Counts et al (2001) reported tardigrades in the tree canopy in the Great Smoky Mountains National Park.

Miller (2004) speculated that because habitat was available in the tree canopy, tardigrades should be present. Since that time Miller's hypothesis has been confirmed, and several studies have found a number of tardigrade species to be significantly more abundant in the canopy ecosystem of Eastern Kansas (Spiers et al 2013, Chappell et al 2015). 
Additionally, other studies have identified several species new to science in the tree canopy (e.g., Haefke et al 2014, Young et al 2016).

As Meyer (2006) ascertained, the variation in tardigrade abundance and diversity among lichen or moss patches of diverse sizes is very high, even when lichens and mosses of the same species from the same site are compared, and the present study reinforces Meyer's findings.

Young et al (2018) studied the density and diversity of tardigrades, rotifers, and nematodes ina Douglas Fir forest canopy in Northern California. They analysed samples of bryophytes, as well as foliose and fruticose lichens. They collected a total of 411 rotifers, 231 tardigrades and 68 nematodes in 51 samples of bryophytes and foliose and fruticose lichens, with tardigrade density being higher in bryophytes and foliose lichens. While in Young et al's (2018) study rotifers were much more common than either tardigrades or rotifers in the present study tardigrades were far more common than either rotifers or nematodes which were present in roughly equal numbers. Young et al. identified twelve tardigrade species similar to the number (11) in the present study.

While there are few studies of the numbers of tardigrade species and densities in the forest canopy, these results are similar to those found in studies of ground dwelling lichens and mosses. Degma et al (2011) in their study of 25 equal sized samples from a growth of the moss Hypnum cupressiforme Hedwig found that eight of the samples had no tardigrades, while the other samples showed from just one tardigrade to as many as 55 specimens, and the number of different species varied between one and two. In total they found some seven different species/genera, four of which were also found in the present study(M. tardigradum, H. convergens, M. hufelandi and Minibiotus sp.).Jönsson (2003) took 101 moss samples from 24 different species, with tardigrades present in $96 \%$ of moss species and $86 \%$ of the subsamples. In total there were sixteen different tardigrade species with six most commonly found including $M$. hufelandi and M. tardigradum. The total number of species recorded was identical to that reported by Dastych (1987) in Polish coniferous forests. Young \& Clifton (2015) in their study of the tardigrades in twelve lichen patches and one moss patch in Oregon found 107 tardigrades in seven of the lichen samples, and in the moss patch. Tardigrade abundance varied dramatically between these samples with five of the lichen samples having none while one had 61 specimens. Their results are similar to those of the present study.

Further, it has been shown that tree species can influence the diversity of tardigrade species (Mitchell et al, 2009). Stratification of tardigrade species in the canopy of a single White Pine has been demonstrated by Miller et al (2013). In a more recent study, Chang et al (2015) documented the presence of populations of tardigrades in the forest canopy in Kansas, and found that there was an increase in the density of tardigrades with increased height in the tree canopy. Young et al (2016) have reported finding a new species, Milnesium swansoni, in the forest canopy in deciduous forest in north eastern Kansas. New species of tardigrades have been described recently from the upper tree canopy (Haefke et al 2014, Young et al 2016, Schlabach et al2018) and species otherwise known only from other continents have been located in North American forest canopies (Spiers et al 2013, Chappell et al 2015, and Tibbs et al 2016).

Miller et al. (2013) have reported greater diversity and density of tardigrades at heights over ten meters in a white pine (Pinus stroba) in Kansas. These studies corroborate other studies of the forest canopy that have confirmed a large portion of global diversity inhabits the forest canopy (Erwin1982, Lowman \& Rinker 2004). Young et al(2016) conclude that "As evidenced by these results from tree canopies in Kansas, the environment of the tardigrade is three dimensional and the upper levels may harbour greater diversity and abundance than we have found for 200 years hunting on the ground, on rocks, and at the base of trees" (p.567). Clearly future studies of the biodiversity of tardigrades must include collections from the tree canopy to further our knowledge of the tardigrade fauna.

\subsection{Distribution of tardigrades to new locations}

The question arises as to how tardigrades disperse to new locations such as tree-living lichens and mosses. A number of authors have suggested that they are passively distributed most likely in the winds and/or in the fur/feathers of animals (Ramazzotti\&Maucci 1983, Kinchin 1994, Miller 1997).

Eggs, and even tuns, being so small and light, could easily be carried by winds to distant locations but this has as of yet been unproven although Nkem et al. (2006) have caught tardigrades in open faced traps in Antarctica. More recently Mogle and his colleagues (2018) have provided evidence of avian-mediated long distance dispersal of tardigrades and Villella et al(2020) have found tardigrades and eggs in the nests of tree voles in Oregon.

The occurrence and dispersal of E. pedicellatum remains an enigma as the species does not exhibit asexual reproduction and diaspores released from fruiting bodies must contact cyanobacteria in order for lichenization to occur. Insects and other animals may act as vectors for diaspores (Maass\&Yetman 2002). It is conceivable that tardigrades could indirectly contribute to this process. Diversity and abundance of micrometazoa vary among second growth and old-growth balsam 
fir forests (Thompson et al. 2013) which could help explain the absence of some cyanolichens in second growth forests. The large clear-cuts typical of industrial forestry in the range of E. pedicellatum may interfere with successful dispersal of the microfauna (Thompson et al. 2013) which could prevent dispersal of rare and ultra-rare cyanolichens and the accompanying micrometazoa, including (rare) tardigrades.

Since L. scrobiculata and the rare E. pedicellatum are both foliose lichens, and corticolous, and often co-located, it is highly probable that the micrometazoa of E. pedicellatum is similar to those of L. scrobiculata.

\section{Acknowledgements}

We would like to thank Mr. Colin Jones who assisted in the collection of the lichens, and Dr. Jean Finney-Crawley who kindly identified the nematodes found in this study. We also thank a number of Memorial University students namely, Ms. Braydi Rice, Ms. Maggie McGuire, and Mr. Ryan Oram and others who assisted in the isolation of the lichen micrometazoa and also assisted with preliminary identifications of the tardigrade specimens. Thanks are also given to Memorial University's Undergraduate Career Experience (MUCEP) program for supporting the hiring of the students.

\section{References}

Argue, C. (1971). Some terrestrial tardigrades from New Brunswick, Canada. Canadian Journal of Zoology49:401-415.

Bartels, P., \& Nelson, D.(2007). An evaluation of species richness estimators for tardigradesin the Great Smoky Mountains National Park. Journal of Limnology 66 (Supplement 1): 104-110.

Bateman, L.,\& Collins, M.(2001).A preliminary account of the tardigrades of Newfoundland. ZoologischerAnzeiger 240:223-232.

Beasley, C.(1978). The tardigrades of Oklahoma. American Midland Naturalist 99:128-141.

Bryndová, M., Stec, D., Schill, R., Michalczyk, L. \& Devetter, M. (2020). Dietary preferences and diet effects on lifehistory traits of tardigrades. Zoological Journal of the Linnean Society 188:865-877.

Chang, L.,Powell, D. Miller, W., \&Lowman, M. (2015). Transactions of the Kansas Academy of Science 118:230-236.

Chappell, B., Parry, D., Miller, W.,\& Lowman, M. (2015). Tardigrades of the canopy: Doryphoribius gibber Beasley and Pilato. (1987) (Eutardigrada: Parachela: Hysibiidae) new records from eastern Kansas, U.S.A. Transactions of the Kansas Academy of Science 118: 38-52.

Collins, M.,\& Bateman, L. (2012). Terrestrial tardigrades of Insular Newfoundland - The biology and distribution of Newfoundland tardigrade species. Lambert Academic Publishing, Saarbrucken, Germany. 151 pages.

Counts, J.,Henley, L., Skrabal, M.,\&Keller, H. (2001). Biological jewels in tree canopies. Transactions of the Missouri Academy of Science 35:69-70.

Dastych, H. (1987). Altitudinal distribution of Tardigrada in Poland. In Bertolani, R. Ed. Biology of Tardigrades. Selected symposia and monographs U.Z.I. Vol. 1. Modena MucchiEditore, 169-176.

Degma, P., Katina, S., \& Sabatovicova, L.(2011). Horizontal distribution of moisture and Tardigrada in a single moss cushion. Journal of Systematics and Evolutionary Research 49 (Suppl. 1):71-77.

Erwin, T. (1982). Tropical forests: their richness in Coleoptera and other arthropod species. The Coleopterist Bulletin 36:74-75.

Goudie, I. (2011).Re-defining old growth and biological diversity in the boreal forest. The Osprey 42:8-15.

Goudie, R. I., Scheidegger, C., Hanel, C.,Munier, A., \& Conway, E. (2011). New models help explain declines in the globally rare boreal felt lichen (Erioderma pedicellatum) in Newfoundland. Endangered Species Research 13: 181-189.

Guidetti, R., Altiero, T., Marchioro, T., Sarzi Amade, 1., Avdonina, A., Bertolani, R., \&Rebecchi, L. (2012).Form and function of the feeding apparatus in Eutardigrada (Tardigrada).Zoomorphology 131:127-148.

Guil, N.,\& Sánchez-Moreno, S. (2013). Fine scale patterns in micrometazoans: Tardigrade diversity, community composition and trophic dynamics in leaf litter. Systematics and Biodiversity 11:181-193.

Hallas, T.,\& Yeates, G. (1972).Tardigrada of the soil and litter of a Danish beech forest.Pedobiologia 12:287-304.

Haefke, B., Spiers, A., Miller, W., \& Lowman, M. (2014). Tardigrades of the canopy: Doryphoribius elleneddiei nov. sp. (Eutardigrada, Parachela, Hypsibiidae), a new species from eastern Kansas, U.S.A. Transactions of the Kansas Academy of Science 117:299-304.

Hidalgo, H., \&Coombs, D. (1985).Tardigrada from Missouri. Transactions of the Kansas Academy of Science 88:121134.

Horning, D.S., Shuster, R.,\& Grigarick, A. (1978).Tardigrada of New Zealand. New Zealand Journal of Zoology 5:185280. 
Jönsson, K. (2003). Population density and species composition of moss-living tardigrades in a boreo-nemoral forest. Ecography 26:356-364.

Kimmel, R.G.,\&Meglitsch, P. (1969). Notes on Iowa Tardigrades. Iowa Academy of Science 76:454-462.

Kinchin, I. (1992). An introduction to the invertebrate microfauna associated with mosses and lichens with observations from maritime lichens on the west coast of the British Isles. Microscopy 36:721-731.

Kinchin, I. (1994). The biology of tardigrades. Portland Press, London, UK. 186 pages.

Lowman, M., \& Rinker, H. (eds.) (2004) (Second edition). Forest canopies. Elsevier Press, Cambridge, MA.544 pages.

Maass, W. S. G., \& Yetman, D. (2002). COSEWIC assessment and status report on the boreal felt lichen Erioderma pedicellatum in Canada. Committee on the Status of Endangered Wildlife in Canada. Environment Canada, Ottawa. $50 \mathrm{pp}$.

Meyer, H. (2006). Small scale spatial distribution variability in terrestrial tardigrade populations. Hydrobiologia 558:133139.

Miller, W. (1997). Tardigrades:Bears of the moss. The Kansas School Naturalist 43:1-15.

Miller,W.(2004). Tardigrades: Moss bears in the canopy. In Forest Canopies, ed. Lowman, M. and H. Rinker. Academic Press pages 251-258. http//dx.doi.org/10.1016/b978-012457553-0/500 18-6

Miller, W., Gallardo, L., \& Clark,T. (2013). Chapter 30: Do water bears climb trees too? Pages 307-311 in Lowman, M.D. (ed.). Tree tops at risk: the challenges of global canopy ecology and conservation. Springer, New York.

Mitchell, C., Miller, W., \&Davis,B. (2009). Tardigrades of North America: influence of substrate on habitat selection. Journal of the Pennsylvania Academy of Science 83:10-16.

Mogle, M., Kimball, S., Miller, W., \& McKown, R. (2018). Evidence of avian-mediated long distance dispersal in American tardigrades. PeerJ6:e5035; DOI 10.7717/peeerj.5035.

Nelson, D., Bartels, P. \&Guil, N. (2018). Chapter 7, Tardigrade Ecology pp. 163-210 in R.O. Schill (Ed.) Water Bears: The biology of Tardigrades, Zoological Monographs 2., Springer Nature, Switzerland.

Nkem, J., Wall, D., Virginia, R., Barrett, J., Broos, J., Porazinska, D., \& Adams, P. (2006). Wind dispersal of soil invertebrates in the McMurdo dry valleys, Antarctica. Polar Biology 29:346-352.

Ramazzotti, G. \&Maucci, W. (1983).IlPhilumTardigrada ( $3^{\text {rd }}$ ed.), Memoriedell'IstitutoItaliano id Idrobiologia Marco Marchi 41:1-1012.

Schlabach, S., Donaldson, E., Hobelman, K., Miller, W., \& Lowman, M. (2018). Tardigrades of the canopy: Milnesium burgessi nov. sp. (Eutardigrada: Apochela: Milnesiidae) a new species from Kansas, U.S.A. Transactions of the Kansas Academy of Science 121:39-48.

Spiers, A., Haefke, B., Miller, W., \&Lowman, M. (2013). Tardigrades in the canopy: Doryphoribius dawkinsiMichalczyk and Kaczmarek, 2010 - New records from eastern Kansas, U.S.A. Transactions of the Kansas Academy of Science 116:125-128. http//dx.doi.org/10.1660/062.117.0319

Stubbs, C. (1989). Patterns of distribution and abundance of corticolous lichens and their invertebrate associates on Quercus rubra in Maine. Bryologist 92:453-460.

Thompson, I. D., Larson, D.J.,\& Montevecchi, W.A. (2003). Characterization of old "wet boreal" forests, with an example from balsam fir forests of western Newfoundland. Environmental Reviews 11(S1): S23-S46.

Tibbs, 1., Emanuels, A., \& Miller, W. (2016).Tardigrades of the canopy: Argentine species Milnesium beatae Roszkowska and Kaczmarek, 2015 (Eutardigrada, Milnesida) discovered in the trees of Kansas, U.S.A. Transactions of the Kansas Academy of Science 119:173-178.

Uetz, G., Meininger, C., \& Snider, J. (1980). Effects of air pollution on microcommunities of invertebrates in lichens and mosses. EPRI RP 1224-2 submitted to Electric Power Research Institute, Palo Alto, California.

Villella, J., Miller, J., Young, A., Carey, G., Emanuels, A., \& Miller, W. (2020). Tardigrades in the forest canopy: Associations with tree vole nests in southwest Oregon. Preprint DOI 10.32942/osf.io/xvcuf

Voegtlin, D. (1982). Invertebrates of the H.J. Andrews Experimental Forest, Western Cascade Mountains, Oregon: a survey of arthropods associated with the canopy of old-growth Pseudotsuga Menziesii. Forest research Laboratory, Oregon State University, Special Publications 4:1-31.

Young, A.,\& Clifton, K. (2015). Tardigrades inhabit lichen and moss in Smith Rock State Park, Oregon. Bulletin of the California Lichen Society 22(2):48-53.

Young, A., Chappell, B., Miller, W., \& Lowman, M. (2016). Tardigrades of the Tree Canopy: Milnesium swansoni sp. nov.(Eutardigrada: Apochela: Milnesiidae) a new species from Kansas, U.S.A.Zootaxa 4072:559-569.

Young, A., Miller, J., Villella, J., Carey, G., \& Miller, W. (2018).Epiphyte type and sampling height in Douglas-fir trees. PeerJ6:e5699; DOI 10.7717/peerj.5699. 